J. Dairy Sci. 96:7591-7602

http://dx.doi.org/10.3168/jds.2013-6615

(c) American Dairy Science Association ${ }^{\circledR}, 2013$.

\title{
Expression of adipokine and lipid metabolism genes in adipose tissue of dairy cows differing in a female fertility quantitative trait locus
}

\author{
Sebastien Elis, ${ }^{*} \dagger \ddagger \S^{1}$ Stephanie Coyral-Castel, ${ }^{*} \dagger \ddagger \S$ Sandrine Freret, ${ }^{*} \dagger \ddagger \S$ Juliette Cognié, ${ }^{*} \dagger \ddagger \S$ \\ Alice Desmarchais, ${ }^{*} \dagger \ddagger \S$ Alice Fatet, ${ }^{*} \dagger \ddagger \S$ Christelle Rame, ${ }^{*} \dagger \ddagger \S$ Eric Briant, ${ }^{*} \dagger \ddagger \S$ \\ Virginie Maillard, ${ }^{*} \dagger \neq \S$ and Joëlle Dupont ${ }^{*}+\ddagger$ \\ *INRA, UMR85 Physiologie de la Reproduction et des Comportements, F-37380 Nouzilly, France \\ †CNRS, UMR 7247 Physiologie de la Reproduction et des Comportements, F-37380 Nouzilly, France \\ łUniversité François Rabelais de Tours, UMR Physiologie de la Reproduction et des Comportements, F-37380 Nouzilly, France \\ §IFCE, UMR Physiologie de la Reproduction et des Comportements, F-37380 Nouzilly, France
}

\begin{abstract}
We have previously characterized 2 haplotypes (Fertil+ and Fertil-) of Holstein dairy cows differing in 1 female fertility quantitative trait locus (QTL) located on chromosome 3 (QTL-Fert-F-BTA3) between positions 9.8 and $13.5 \mathrm{cM}$. This QTL is composed of 124 genes, some of them being involved in metabolism or reproduction. Primiparous Fertil+ and Fertil- cows exhibited 69 and $39 \%$ pregnancy rate at first service, respectively. A difference in plasma nonesterified fatty acid concentrations observed between both haplotypes might indicate a difference in adipose tissue mobilization. We compared adipose tissue gene expression in Fertil+ and Fertil- cows during their second lactation, at 2 physiological stages, implying either intense lipid mobilization (1 wk postpartum) or fat storage (5 mo of gestation). We investigated by reverse-transcription quantitative $\mathrm{PCR}$ the mRNA gene expression of 5 positional candidate genes located in the QTL-Fert-FBTA3, as well as 18 other functional candidate genes encoding proteins involved in lipid metabolism and several adipokines. Among them, genes involved in either lipolysis or lipogenesis were chosen as controls because they were previously described in dairy cow adipose tissue. A hierarchical clustering was performed to group genes according to their expression pattern, allowing 2 clusters to be determined. Cluster 1 was composed of genes that were overexpressed during mobilization (ADIPOQ, ADIPOR2, LIPE, FABP4, PLIN1, RARRES, LEPR, and CPT1A) and cluster 2 of genes overexpressed during reconstitution of body reserves ( $A C A C A, F A S N$, and $S C D$ ). Genes belonging to cluster 1 (LIPE, FABP 4, PLIN1, and CPT1A) are known to be involved in lipolysis and fatty acid oxidation, and genes belonging to cluster $2(A C A C A, F A S N$, and $S C D)$
\end{abstract}

Received January 24, 2013

Accepted August 22, 2013.

${ }^{1}$ Corresponding author: sebastien.elis@tours.inra.fr are known to be involved in fatty acid synthesis. The expression of 5 genes from cluster 1 was correlated to plasma nonesterified fatty acid levels and thus to mobilization of body reserves in dairy cows (ADIPOQ, ADIPOR2, LIPE, PLIN1, and FABP4). During the mobilization stage, none of the positional candidate genes belonging to QTL-Fert-F-BTA3 (ADAR, MTX1, SHC1, SPTA1, and PAQR6) showed a difference in expression between the 2 haplotypes. Interestingly, $A D I P O Q$ and $A D I P O R 2$ were the only genes showing a significant mRNA overexpression in Fertil- cows at the mobilization stage. Further studies focusing on plasma adiponectin level and adipokine actions on the ovary are needed to investigate its potential role in dairy cow fertility.

Key words: adiponectin expression, adipose tissue, fertility, mobilization

\section{INTRODUCTION}

Reproductive performance in cows is influenced by nutritional and metabolic status, as previously reviewed (Butler, 1998, 2000; Staples et al., 1998; Roche, 2006; Leroy et al., 2008). Parturition and lactogenesis cause metabolic and endocrine changes in dairy cows (Grummer et al., 1995), which lead to a negative energy balance. Therefore, energy has to be mobilized from body reserves, mainly from fat. With mobilization of 50 to $60 \mathrm{~kg}$ of fat during early lactation, lipolysis is thus the essential process to support energy supply for all biological functions [for review, see Schröder and Staufenbiel (2006)].

Until recently, white adipose tissue was considered as a passive organ for the storage and mobilization of triglycerides during periods of excess or deficit of energy. Adipose tissue is now known to produce and secrete several signaling proteins, collectively termed adipokines. In rodents and humans, adipokines are reported to play important roles in regulating adipocyte differentiation and metabolism (Karastergiou and Mohamed- 
Ali, 2010), as well as to exert some well-known effects on reproductive functions (Campos et al., 2008; Briana and Malamitsi-Puchner, 2010; Tersigni et al., 2011; Dupont et al., 2012). Moreover, some publications suggest a role of adipose tissue secretion in sustaining proper fertility; indeed, fat transplantation in leptin knockout mice restores fertility in these animals (Klebanov et al., 2005; Pereira et al., 2011). Leptin is suggested to be a link between energy balance and reproductive function (Diskin et al., 2003). In bovines, adipokines are also expressed in adipose tissue (Komatsu et al., 2003; Lemor et al., 2009; Song et al., 2010), and both adiponectin (Lagaly et al., 2008; Maillard et al., 2010) and resistin (Maillard et al., 2011; Spicer et al., 2011) affect in vitro steroidogenesis of bovine granulosa cells.

We previously characterized 2 groups of primiparous Holstein cows differing on a female fertility QTL located on chromosome 3 (QTL-Fert-F-BTA3) and exhibiting either 69\% (Fertil+ haplotype) or 39\% (Fertil- haplotype) pregnancy rate at first service, as assessed by pregnancy diagnosis $35 \mathrm{~d}$ after AI (Coyral-Castel et al., 2011). These haplotypes were also shown to be different in their in vitro embryo development ability, the Fertil- embryo having developmental delay (CoyralCastel et al., 2012a). The QTL-Fert-F-BTA3 is located between positions 9.8 and $13.5 \mathrm{cM}$ (Guillaume et al., 2007; Ben Jemaa et al., 2008; Druet et al., 2008). This QTL is composed of 124 genes, some of them involved in metabolism or reproduction [adenosine deaminase, RNA specific $(\boldsymbol{A D A R})$, metaxin 1 ( $\boldsymbol{M} \boldsymbol{T} \boldsymbol{X} \mathbf{1})$, and progestin and adipoQ receptor $(\boldsymbol{P A Q R \boldsymbol { G }})$, among others]. As examples, ADAR is related to ovarian neoplasms in humans (Urunsak et al., 2012) and MTX1 is required for proper embryo development in mice (Bornstein et al., 1995); PAQR6 is a member of the progestin and adiponectin receptor family and is involved in rapid steroid response in pigs (Zhao et al., 2011).

The present study was designed to explore lipid metabolism and also to compare adipokine expression in adipose tissue during second lactation. We hypothesized that either reserve mobilization or adipose tissue hormone secretion could explain the difference in fertility between these 2 groups of cows (Fertil+ and Fertil-) through QTL genes. We compared the expression of 5 positional candidate genes located within the QTL, as well as 18 other functional candidate genes, at $1 \mathrm{wk}$ postpartum (1wpp), which is a stage of intense lipid mobilization. The chosen functional candidate genes were genes encoding proteins involved in lipid metabolism (lipolysis/lipogenesis) and adipokines and their receptors (as some adipokines are involved in reproduction). An additional physiological stage corresponding to a period of fat storage at 5 mo of gestation (5mges) was also included to validate the study.

\section{MATERIALS AND METHODS}

\section{Animals}

All experimental protocols were approved by an ethics committee [Comité d'Ethique en Expérimentation Animale Val de Loire (CEEA VdL) protocol, registered under ref. 2012-01-1] and were consistent with the guidelines provided by the French Council for Animal Care. Nineteen Holstein dairy cows, born in 2006, were monitored during the first months of their second lactation. Dairy cows were managed in straw-bedded yards and fed ad libitum with a TMR composed of $64.5 \%$ maize silage, $10 \%$ soybean, $15 \%$ concentrate, $10 \%$ dehydrated alfalfa, and $0.5 \%$ calcium oxide $(\mathrm{CaO})$. The pregnancy rate was determined at 3 different times after insemination: $21 \mathrm{~d}$ after AI by plasma progesterone assay (blood sampling by caudal venipuncture), $35 \mathrm{~d}$ after AI by ultrasonographic examination, and $90 \mathrm{~d}$ after AI by transrectal palpation. It was calculated as the number of pregnant females divided by the total number of inseminated females.

\section{Zootechnical Parameters}

During the first lactation, milk production and composition (fat and protein content) were registered weekly. Cows were fed ad libitum in weighing feeders so that we could measure their DMI and thus extrapolate their empty BW. Blood samples were collected weekly before feed distribution to measure plasma NEFA, glucose, and urea levels. Pregnancy rates at first service (at d 21, 35, and 90 after AI) in these primiparous cows were compared between haplotypes using a chi square test, with PROC FREQ of SAS software (SAS Institute, 2009). Zootechnical and metabolic data were analyzed using a linear mixed model, with PROC MIXED of the SAS for repeated measures. For analyses of DMI, milk yield, milk fat and protein contents, 2 covariates, empty BW at 1wpp, and the corresponding EBV were also included in the model, as these covariates are known to affect DMI, milk production, and composition (Coyral-Castel et al., 2012b). Least squares means estimated by the model were subsequently compared between haplotypes each week post or peripartum with a Student's $t$-test (LSM statement of PROC MIXED). Results are presented in graphs as means \pm standard error of the mean (Figure 1).

\section{Sample Collection}

During the second lactation, biopsies of adipose tissue were collected from the same animals at 1 wpp and 5 mges. Cows were fasted for $12 \mathrm{~h}$ before surgery and blood samples for metabolic measurement were col- 


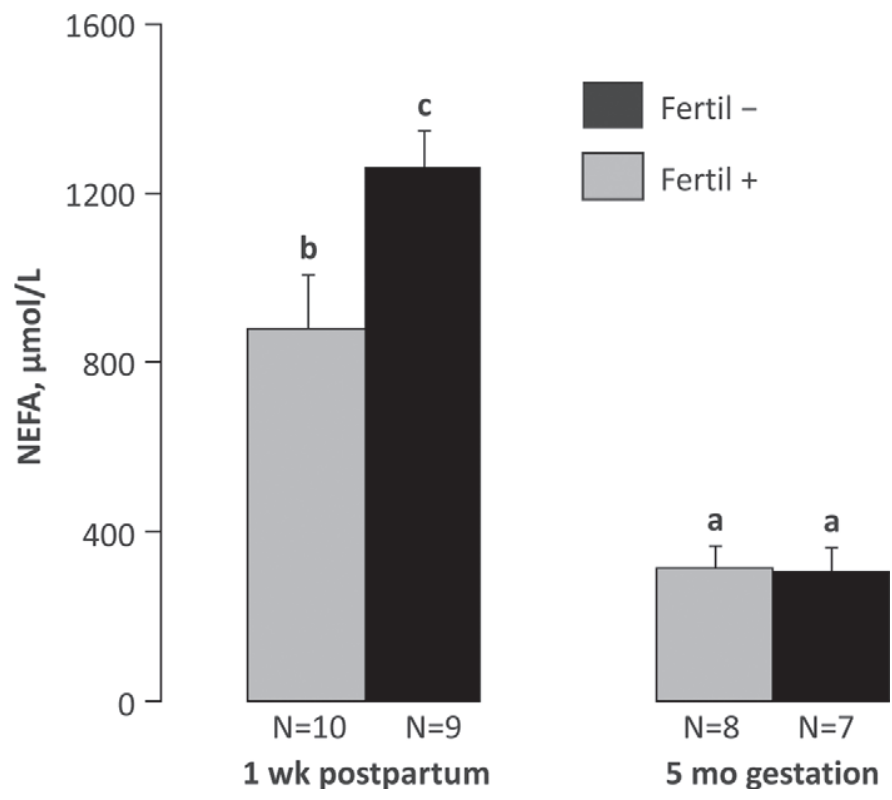

Figure 1. Mean plasma NEFA level measured on the day of sample collection (1 wk postpartum and 5 mo of gestation in second lactation) in both Fertil+ and Fertil- cows (exhibiting 69 and 39\% pregnancy rate at first service, respectively). Results are presented as means \pm SEM. Bars with different letters $(\mathrm{a}-\mathrm{c})$ differ $(P<0.05)$.

lected on the day of the biopsy. Anesthesia was induced with injections of 12 to $14 \mathrm{mg}$ of Xylazine i.v. (Rompun; Bayer AG, Leverkusen, Germany) and an injection of $200 \mathrm{mg}$ of Lidocaine s.c. (Lurocaïne; Vétoquinol SA, Lure, France). Subcutaneous fat was collected from the dewlap.

\section{Adipose Tissue mRNA Extraction, Real-Time Reverse-Transcription PCR, and Hierarchical Clustering}

Total RNA was extracted from $200 \mathrm{mg}$ of adipose tissue and DNase digested using an RNeasy Mini kit (Qiagen GmbH, Hilden, Germany) according to the manufacturer's instructions. The RNA quantity was assessed with a NanoDrop ND-1000 Spectrophotometer (Nyxor Biotech, Paris, France) and the RNA quality was evaluated with an Agilent 2100 Bioanalyzer using an RNA 6000 Nano assay protocol (Agilent Technologies France SAS, Massy, France). One of the samples was removed because of poor mRNA quality; thus, 18 dairy cows were used for the expression study. Reverse transcription was performed on $1 \mu \mathrm{g}$ of total RNA extracted from adipose tissues using Moloney murine leukemia virus reverse transcriptase I with an oligo dT primer mix (Promega Corp., Madison, WI) according to the manufacturer's instructions. Specific sets of primer pairs (Sigma-Genosys, Lyon, France) designed using
Primer3Plus software (Rozen and Skaletsky, 2000) to amplify fragments of 23 different transcripts are shown in Table 1. Real-time PCR reactions were carried out in $20 \mu \mathrm{L}$ containing primers at a final concentration of 150 $\mathrm{n} M$ of each, $5 \mu \mathrm{L}$ of the reverse-transcription reaction diluted 1/30 (30 ng of cDNA), and qPCR MasterMix Plus for SYBR Green I (Bio-Rad, Marnes-la-Coquette, France) according to the manufacturer's instructions. Real-time PCR was performed using a MyiQ realtime PCR system (Bio-Rad). The geometric mean of 4 housekeeping genes was used to normalize gene expression. The relative amounts of gene transcripts (R) were calculated according to the equation $\mathrm{R}$ $=\left(\mathrm{E}_{\text {gene }}{ }^{-\mathrm{Ct}}\right.$ gene $) /\left[\right.$ geometric mean $\left(\mathrm{E}_{P P I A}{ }^{-\mathrm{Ct}}{ }^{P P I A}\right.$; $\left.\left.\mathrm{E}_{R P S 9}{ }^{-\mathrm{Ct} R P S 9} ; \mathrm{E}_{R P L 19}{ }^{-\mathrm{Ct} R P L 19} ; \mathrm{E}_{G A P D H}{ }^{-\mathrm{Ct} G A P D H}\right)\right]$, where $\mathrm{Ct}$ is the cycle threshold and E the PCR efficiency for each primer pair (Table 1). The hierarchical classification of PCR data was performed with Cluster 3.0 software (Stanford University, Stanford, CA), using supervised average linkage clustering with a Euclidian distance analysis (Eisen et al., 1998).

\section{Candidate Genes}

Among the 23 candidate genes, 5 genes $[A D A R$, MTX1, PAQR6, Src homology 2 domain containing (SHC1) and spectrin a erythrocytic (SPTA1)] are located in the QTL-Fert-F-BTA3 and were, thus, positional candidate genes. These genes are reported to be involved in either metabolism or reproduction. Adenosine deaminase, RNA specific is related to ovarian neoplasms in humans (Urunsak et al., 2012), MTX1 is required for proper embryo development in mice (Bornstein et al., 1995), PAQR6 is a member of the progestin and adiponectin receptor family and is involved in rapid steroid response in pigs (Zhao et al., 2011), and SPTA1 and SHC1 were added to the study because they have been reported to be expressed in the human ovary $(\mathrm{Su}$ et al., 2002; Dezső et al., 2008).

The 18 other genes are functional candidate genes. Nine genes: adiponectin $(\boldsymbol{A D I P O Q})$, adiponectin receptor 1 and 2 (ADIPOR1 and ADIPOR2), leptin $(\boldsymbol{L} \boldsymbol{E P})$, leptin receptor $(\boldsymbol{L} \boldsymbol{E P R})$, nicotinamide phos-

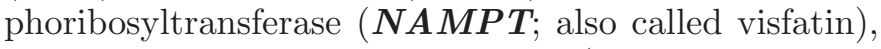
retinoic acid receptor responder $2(\boldsymbol{R A R R} \boldsymbol{R} \boldsymbol{S} 2$; also called chemerin), resistin ( $\boldsymbol{R E} \boldsymbol{T N})$, and tumor necrosis factor $\alpha(\boldsymbol{T N F} \boldsymbol{\alpha})$ were studied because they are adipokines or their receptors and have, thus, been reported to affect metabolism and, for some of them, reproduction in dairy cows. The 9 remaining genes [acetyl-CoA carboxylase ( $\boldsymbol{A} \boldsymbol{C A} \boldsymbol{C A}$; also called ACC), carnitine palmitoyl transferase 1A and $2(\boldsymbol{C P T} \mathbf{A}$ and $\boldsymbol{C P T 2})$, FA-binding protein $4(\boldsymbol{F A B P} 4)$, FA synthase $(\boldsymbol{F A} \boldsymbol{S N}$; 
Table 1. Oligonucleotide primer sequences

\section{Primer}

\begin{tabular}{|c|c|c|c|c|c|c|}
\hline \multirow[b]{2}{*}{ Abbreviation } & \multirow[b]{2}{*}{ Name } & \multirow{2}{*}{$\begin{array}{l}\text { GenBank } \\
\text { accession no. }\end{array}$} & & \multirow[b]{2}{*}{ Size, bp } & \multirow[b]{2}{*}{ Efficiency } \\
\hline & & & Forward $5^{\prime}-3^{\prime}$ & Reverse $5^{\prime}-3^{\prime}$ & & \\
\hline$A C A C A$ & Acetyl CoA carboxylase & NM_174224 & TGCTTCCCATTTGCCATC & CTGCCATCCTCACGACCT & 188 & 2.14 \\
\hline$A D A R$ & Adenosine deaminase, RNA specific & XM_581374 & CCTGCAGCCTGTGTATCTCA & ATACACTGACTCGGCCAACC & 167 & 1.91 \\
\hline$A D I P O Q$ & Adiponectin & NM_174742 & CACCTTCACAGGCTTCCTTC & AGACTGTCCTGGGAACATGG & 219 & 2.24 \\
\hline ADIPOR 1 & Adiponectin receptor 1 & NM_001034055 & GGCTCTACTACTCСТTCTAC & ACACCCCTGCTCTTGTCTG & 144 & 2.01 \\
\hline ADIPOR2 & Adiponectin receptor 2 & NM_001040499 & GGCAACATCTGGACACATC & CTGGAGACCCCTTCTGAG & 200 & 1.95 \\
\hline CPT1A & Carnitine palmitoyl transferase 1 & FJ415874 & TCCTGGTGGGCTACCAATTA & TGCGTCTGTAAAGCAGGATG & 181 & 2.34 \\
\hline СРT2 & Carnitine palmitoyl transferase 2 & NM_001045889 & TGTGCCTTCCTTCCTGTCTTGG & CGATGGGGTCTGGGTAAACGA & 111 & 2.03 \\
\hline$G A P D H$ & Glyceraldehyde 3-phosphate dehydrogenase & NM_001034034 & TTCAACGGCACAGTCAAGG & ACATACTCAGCACCAGCATCAC & 119 & 2.18 \\
\hline PPIA & Cyclophilin A & NM_178320 & GCATACAGGTCCTGGCATCT & TGTCCACAGTCAGCAATGGT & 217 & 2.01 \\
\hline$F A B P 4$ & FA-binding protein 4 & NM_174314 & TGGTGCTGGAATGTGTCATGA & TGGAGTTCGATGCAAACGTC & 101 & 2.09 \\
\hline FASN $^{\top}$ & FA synthase & AY343889 & CACTCCATCCTCGCTCTCC & GCCTGTCATCATCTGTCACC & 181 & 2.32 \\
\hline$L I P E$ & Hormone-sensitive lipase & NM_001080220 & GAGTTTGAGCGGATCATTCA & TGAGGCCATGTTTGCTAGAG & 102 & 2.07 \\
\hline LEP & Leptin & NM_173928 & GGCTGTCCACAGGAGAAGAG & AGTGAGAGGGAGCTGGAACA & 233 & 2.23 \\
\hline$L E P R$ & Leptin receptor long form & AB199589 & ACCACACCTTCCGTTCTCAG & GGGACAACACTCTTGACTC & 164 & 2.26 \\
\hline MTX1 & Metaxin 1 & NM_001040608 & AGGAGGAGCTGGAGAAGGAG & CAGGGGAAGTACAGGCTGAG & 244 & 2.06 \\
\hline$N A M P T$ & Visfatin & XM_878509 & CAGATCCGGAGTGTTACTGG & CCTATGCCAGCAGTCTCTTG & 211 & 2.19 \\
\hline PAQR 6 & Progestin and adipoQ receptor & NM_001046225 & TCCCTTTCTGTTCGACAACC & AGGCAGATGAGAGGCAAAGA & 154 & 1.93 \\
\hline PLIN1 & Perilipin & NM_001083699 & CCTCTTCACAGGCTGAGTCC & GGTGGATTCCTTATCGCTGA & 230 & 2.03 \\
\hline PLIN2 & Adipophilin & NM_173980 & ACAACACACCCCTCAACTGG & CTGCCTGCCTACTTCAGACC & 211 & 2.04 \\
\hline RARRES2 & Chemerin & NM_001046020 & GCTGTCGGAAGAAAGACTGG & AAACTGTCCGGGGAGGTAGT & 236 & 2.04 \\
\hline RETN & Resistin & NM_183362 & AGTCCACAGAGAGGCACCTG & TGGTGACCTCCTGGATCTTC & 133 & 2.04 \\
\hline RPL19 & Ribosomal protein L19 & BC102223 & AATCGCCAATGCCAACTC & СССТTTCGCTTACCTATACC & 156 & 2.2 \\
\hline RPS9 & Ribosomic protein S9 & BC148016 & GGAGACCCTTCGAGAAGTCC & GGGCATTACCTTCGAACAGA & 180 & 2.05 \\
\hline$S C D$ & Stearoyl-CoA desaturase 1 & NM_173959 & CTGGCTGGTGAATAGTGCTG & AAGGTGTGGTGGTAGTTGTGG & 129 & 2.05 \\
\hline SHC1 & Src homology 2 domain containing & NM_001164061 & AAGTCAACGGGGACTTCCTT & GGCAAGTGATTGTCCATGTG & 187 & 2.11 \\
\hline SPTA 1 & Spectrin $\alpha$ erythrocytic & XM_581362 & ACTGGGAACGTATTCGCAAC & TGCTGATGCCTGTCCAGTAG & 190 & 2.34 \\
\hline$T N F$ & Tumor necrosis factor $\alpha$ & NM_173966 & CTTCTGCCTGCTGCACTTCG & GAGTTGATGTCGGCTACAACG & 153 & 2.32 \\
\hline
\end{tabular}


also called FAS), hormone-sensitive lipase ( $\boldsymbol{L I P E}$; also called HSL), perilipin 1 and 2 (PLIN1 and PLIN2), and stearoyl-CoA desaturase $(\boldsymbol{S C D})]$ are involved in lipid metabolism. They are involved in lipolysis ( $L I P E$, PLIN1, PLIN2, and FABP4), FA oxidation (CPT1A and CPT2), or in FA synthesis (ACACA, FASN, and $S C D)$.

\section{Protein Extraction and Western Blotting}

Adipose tissue total proteins were extracted on ice in lysis buffer [10 m $M$ Tris (pH 7.4), $150 \mathrm{~m} M \mathrm{NaCl}, 1 \mathrm{~m} M$ EDTA, $1 \mathrm{~m} M$ EGTA, and $0.5 \%$ Igepal] containing protease inhibitors [2 $\mathrm{m} M$ phenylmethylsulfonyl fluoride (PMSF) and $10 \mathrm{mg}$ of leupeptin $/ \mathrm{mL}$ ] and phosphatase inhibitors (100 $\mathrm{m} M$ sodium fluoride, $10 \mathrm{~m} M$ sodium pyrophosphate, and $2 \mathrm{~m} M$ sodium orthovanadate). After centrifugation at $16,000 \times g$ for $30 \mathrm{~min}$ at $4^{\circ} \mathrm{C}$, the protein concentration was determined in the supernatants (kit BC assay protein quantification; Interchim, Montluçon, France). Protein extracts ( $80 \mu \mathrm{g}$ per lane) were separated by electrophoresis on $12 \%$ (wt/vol) SDS-polyacrylamide gel and transferred to a $0.45-\mu \mathrm{m}$ nitrocellulose membrane (Bio Trace NT; Pall Corp., VWR International, Fontenay-sous-Bois, France). Membranes were then blocked with $5 \%$ nonfat dry milk powder (NFDMP) or 5\% BSA in Tris-buffered saline (TBS; $2 \mathrm{~m} M$ Tris- $\mathrm{HCl}$ and $15 \mathrm{mM} \mathrm{NaCl}, \mathrm{pH}$ 7.4), containing $0.1 \%$ Tween-20 (TBST), for $45 \mathrm{~min}$ at room temperature. The membranes were incubated overnight at $4^{\circ} \mathrm{C}$ with appropriate antibodies (dilution of $1 / 1,000)$ in TBST with $5 \%$ NFDMP or $5 \%$ BSA. After being washed several times in TBST, membranes were incubated for $2 \mathrm{~h}$ at room temperature with a horseradish peroxidase-conjugated anti-rabbit or antimouse (dilution 1/5 000) in TBST with 5\% NFDMP. After washing again in TBST, the signal was detected by enhanced chemiluminescence (Western Lightning Plus-ECL; PerkinElmer Life and Analytical Sciences, Courtaboeuf, France). Signal acquisition was performed using a CCD camera G:Box (Syngene UK, Cambridge, UK) with GeneSnap 7.09 software (Syngene UK) and the analysis of signal intensity was performed with GeneTools 4.01 software (Syngene UK). Results are expressed in arbitrary units as the signal intensity normalized to the signal for vinculin, a housekeeping protein.

\section{Statistical Analysis}

During the second lactation, correlations between quantitative parameters for gene expression were tested using Pearson correlations with PROC CORR SAS (SAS Institute, 2009). All other experimental data
(mRNA and protein expression, and NEFA at 1wpp and 5mges) are presented as means \pm standard error of the mean. Analysis of variance was used to assess differences (StatView version 5.0; SAS Institute Inc., Cary, NC). If ANOVA revealed significant effects, the means were compared using Fisher's test, considering $P<0.05$ as significant. Pregnancy rates were compared using the Chi square test (PROC FREQ of SAS).

\section{RESULTS}

\section{Zootechnical Parameters}

In the present study, the expression of several adipose tissue genes was compared for the first time at 2 different physiological stages in 2 groups of Holstein dairy cows differing for a female fertility QTL (QTL-Fert-FBTA3, Fertil- and Fertil+ haplotypes). During their first lactation, Fertil- cows had a lower pregnancy rate at $\mathrm{d} 21$ after $\mathrm{AI}[56 \%(\mathrm{n}=5 / 9)$ vs. $100 \%(\mathrm{n}=10 / 10)$ in Fertil + cows; $P=0.02)]$ and at d 35 after AI $[33 \%$ (n $=3 / 9)$ vs. $80 \%(\mathrm{n}=8 / 10)$ in Fertil + cows; $P=0.04)]$ and tended to have a lower pregnancy rate at $\mathrm{d} 90$ after insemination $[33 \%(\mathrm{n}=3 / 9)$ vs. $70 \%(\mathrm{n}=7 / 10)$ in Fertil+ cows; $P=0.11$ ).

Moreover, as described previously, plasma concentration of NEFA was similar in both haplotypes, from 4 wk before calving to $16 \mathrm{wk}$ postpartum, except at $6 \mathrm{wk}$ postpartum when it tended to be higher in Fertil- than in Fertil+ primiparous cows $(P=0.083)$. Energy balance was similar for the 2 haplotypes over the whole lactation, except in the first week postpartum when it was more negative for Fertil- than for Fertil+ primiparous cows (Coyral-Castel et al., 2012b). During the second lactation of these 19 cows, plasma NEFA levels were also monitored and were significantly greater at 1 wpp compared with 5mges in both haplotypes. Furthermore, when looking at the period of intense mobilization, plasma NEFA levels were significantly greater (Figure 1) in Fertil- samples $(P<0.05)$, which could suggest that the Fertil- cows mobilized their energy reserves on a more intensive pattern than the Fertil+ cows during early lactation.

\section{Adipose Tissue Gene Expression}

To further investigate this difference in mobilization, we measured the expression of 23 genes coding for adipokines and genes involved in lipid metabolism (Table 1 ) in adipose tissue at $1 \mathrm{wpp}$ and $5 \mathrm{mges}$. To group genes with similar expression patterns, supervised hierarchical clustering of our data was performed with samples arranged first according to the physiological stage (either 1 wpp for lipid mobilization or 5mges for lipid storage) 
and then to the genetic background of the sample (sample from Fertil+ or Fertil- haplotype). A Euclidian distance/average linkage analysis, performed with Cluster 3.0 software, enabled us to find 2 different clusters exhibiting a high threshold ( $>0.9$; Figure 2). Cluster 1 was composed of 9 genes overexpressed at 1wpp during mobilization (ADIPOQ, ADIPOR2, LEPR, RARRES2, PLIN1, LIPE, FABP 4, CPT1A, and CPT2), and cluster 2 was composed of 6 genes overexpressed at 5mges during reconstitution of body reserves ( $L E P, A C A C A$, FASN, SCD, SPTA1, and MTX1). The graphical representation of the analysis is shown in Figure 2 and the expression data of all genes are provided in Table 2. Graphical representation of expression profiles of each gene is provided as Supplementary Figures S1, S2, and S3 (available online at http://dx.doi.org/10.3168/ jds.2013-6615. In cluster 1, 7 genes (ADIPOR2, LEPR, RARRES2, PLIN1, LIPE, FABP4, and CPT1A) were significantly overexpressed at 1wpp compared with 5mges, with $A D I P O Q$ showing the same tendency ( $P$ $=0.062)$. In cluster 2,2 genes $(F A S N$ and $S C D)$ were significantly overexpressed at 5mges compared with 1wpp, with $A C A C A$ and MTX1 showing the same tendency $(P=0.076)$. Interestingly, among all the studied genes, $A D I P O R 2$ and $A D I P O Q$ were expressed at a significantly greater level (1.48- and 1.49-fold increase, respectively) in Fertil- cows than in Fertil+ cows at 1wpp $(P=0.0064$ and $P=0.0008$, respectively; Table $2)$. Two other genes, NAMPT and ADAR, showed significant differences between the haplotypes at 5mges ( $P$ $=0.0222$ and 0.0120 , respectively; Table 2).

\section{Candidate Gene mRNA Expression in Adipose Tissue and Mobilization of Reserve}

Pearson correlations between the mRNA expression levels of the 23 studied genes and plasma NEFA levels were analyzed. Five genes (ADIPOR2, LIPE, PLIN1, $F A B P 4$, and $A D I P O Q$ ) showed significant positive correlation $(\mathrm{r}>0.5, P<0.002)$ with plasma NEFA level (Figure 3).

\section{Protein Level Expression of Candidate Genes}

Protein level was evaluated by Western blotting in adipose tissue collected at 1wpp and 5mges for both Fertil- and Fertil+ cows. At 5mges, SCD and FAS were significantly more expressed than at 1wpp, which is consistent with mRNA expression results (Figure 4). No other differences in protein expression were observed.

\section{DISCUSSION}

In the present study, we compared for the first time the expression of 5 positional and 18 functional candi- date genes in adipose tissue at 2 different physiological stages in 2 groups of Holstein dairy cows differing for a female fertility QTL (QTL-Fert-F-BTA3 in Fertil- and Fertil+ haplotypes). The most interesting finding in our study was that 2 genes (ADIPOQ and ADIPOR2) were expressed with a 1.48- and 1.49-fold increase in Fertil- haplotypes compared with Fertil+, respectively, at the energy mobilization stage. These genes were also positively correlated with plasma NEFA level. Moreover, 1 gene located within the QTL $(A D A R)$ was differentially expressed between the haplotypes during the gestation stage.

Concerning gene expression, our model showed that genes playing a role in lipolysis (LIPE and PLIN1; Yeaman et al., 1994; Sumner and McNamara, 2007; Elkins and Spurlock, 2009) and lipid transport (FABP4; Shen et al., 1999) were overexpressed during the mobilization stage. Furthermore, we found a decrease in $S C D$ and FASN mRNA expression at 1wpp. Stearoyl-CoA desaturase is involved in the lipogenic pathway [for review, see Flowers and Ntambi (2009)]. Fatty acid synthase activity is enhanced under lipogenic conditions; it is the final enzyme in the FA synthesis process [for review, see Foufelle et al. (1996) and Griffin and Sul (2004)]. These genes, involved in the lipolysis/lipogenesis pathways have previously been reported to increase or decrease remarkably in cow adipose tissue during early lactation (Sumner and McNamara, 2007; Thorn et al., 2008; Lemor et al., 2009; Sadri et al., 2011; Sumner-Thomson et al., 2011).

Adiponectin and ADIPOR2 were differentially expressed between Fertil+ and Fertil- haplotypes. Through ADIPOR2 binding, secreted adiponectin leads to increased AMP-activated protein kinase (AMPK) phosphorylation (Narasimhan et al., 2005) and thus to increased expression of molecules involved in FA transport as well as FA oxidation in numerous tissues (Fruebis et al., 2001; Kadowaki and Yamauchi, 2005). Several studies suggested that adiponectin might be involved in the control of the female reproductive system [for review, see Mitchell et al. (2005)]. Indeed, transgenic female mice exhibiting a 2 -fold increase in adiponectin plasma level are infertile (Combs et al., 2004). In addition, adiponectin and its receptors are expressed in ovarian cells of different species (Mitchell et al., 2005; Campos et al., 2008), including dairy cows (Lagaly et al., 2008; Maillard et al., 2010), and especially in oocytes, granulosa, and theca cells. Moreover, these studies showed that recombinant adiponectin affects ovarian steroidogenesis in dairy cows (Lagaly et al., 2008; Maillard et al., 2010). Other studies also suggest that adiponectin could affect oocyte maturation and early embryo development in mouse and human in vitro fertilization procedures (Richards et al., 2012), 


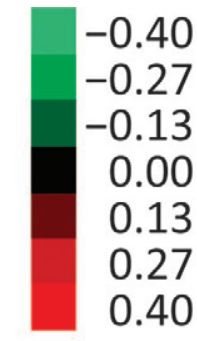

1 wpp 5 mges

0.00

0.13

0.27

0.40
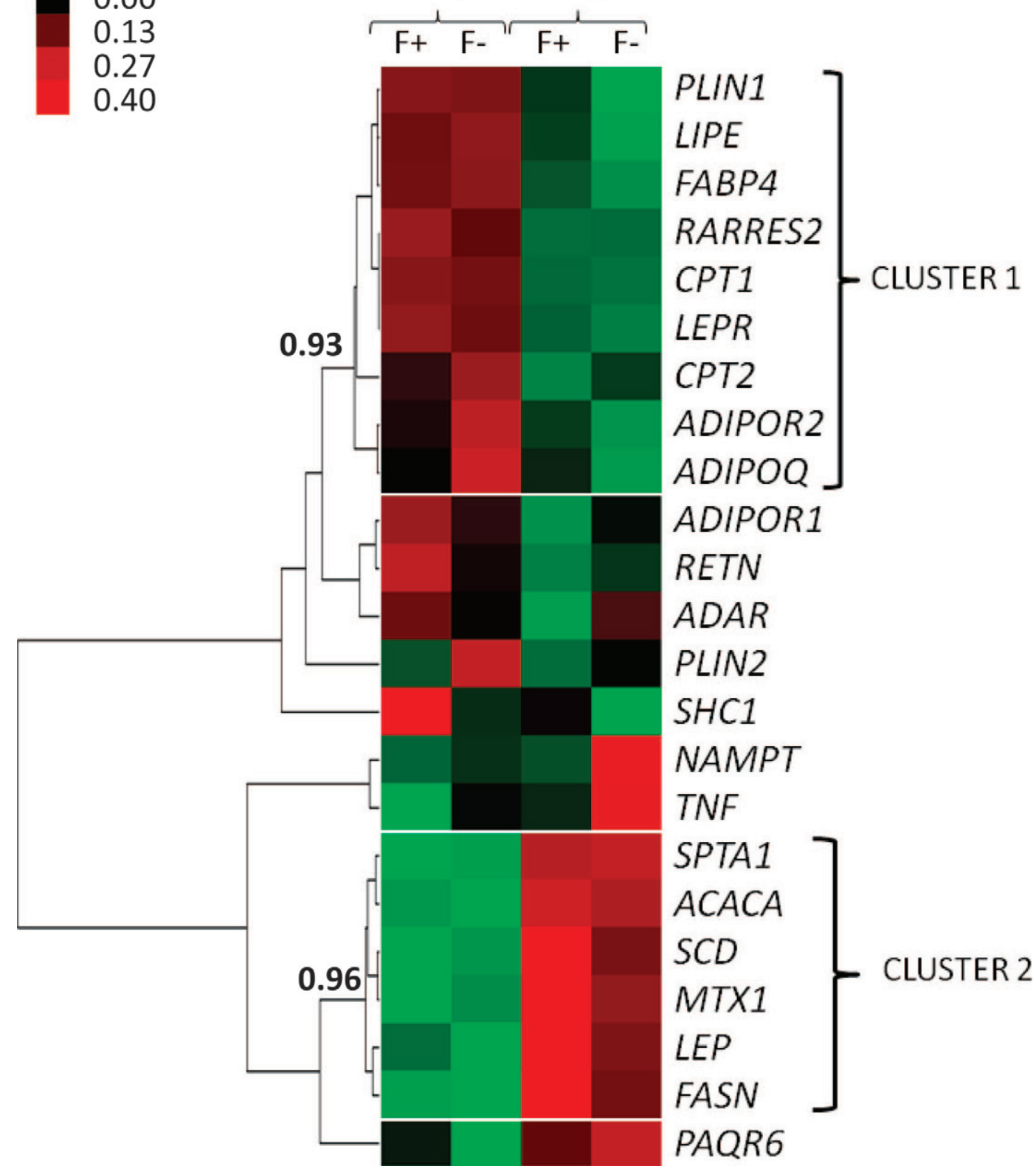

Figure 2. Supervised hierarchical clustering of candidate genes during mobilization and reconstitution stages in adipose tissue. Real-time PCR analysis was performed in duplicate on samples taken at 2 different stages [ 1 wk postpartum (1wpp) and 5 mo of gestation (5mges)] in Fertil- $(\mathrm{F}-)$ and Fertil $+(\mathrm{F}+)$ haplotypes (exhibiting 69 and 39\% pregnancy rate at first service, respectively), with 6 to 9 biological replicates. Supervised hierarchical clustering of genes was performed using Cluster 3.0 software (Stanford University, Stanford, CA). Two clusters stand out (cluster 1 and cluster 2). Node correlation thresholds are indicated for each cluster. PLIN1 = perilipin; LIPE = hormone-sensitive lipase; $F A B P 4=$ FA-binding protein $4 ; R A R R E S 2=$ chemerin $C P T 1=$ carnitine palmitoyl transferase $1 ; L E P R=$ leptin receptor long form; $C P T 2=$ carnitine palmitoyl transferase $2 ; A D I P O R 2=$ adiponectin receptor $2 ; A D I P O Q=$ adiponectin; $A D I P O R 1=\operatorname{adiponectin}$ receptor $1 ; R E T N=$ resistin; $A D A R=$ adenosine deaminase, RNA specific; $P L I N 2=$ adipophilin; $S H C 1=$ Src homology 2 domain containing; $N A M P T=$ visfatin $T N F=$ tumor necrosis factor $\alpha ; S P T A 1=$ spectrin $\alpha$ erythrocytic; $A C A C A=$ acetyl CoA carboxylase; $S C D=$ stearoyl-CoA desaturase $1 ; M T X 1$ $=$ metaxin $1 ; L E P=$ leptin; $F A S N=$ FA synthase; $P A Q R 6=$ progestin and adipoQ receptor. 
Table 2. Adipose tissue relative gene expression at the mobilization stage [1 wk postpartum (1wpp)] and reconstitution stage [5 mo of gestation (5mges)] in both Fertil+ and Fertil- haplotypes (exhibiting 69 and 39\% pregnancy rate at first service, respectively) ${ }^{1}$

\begin{tabular}{|c|c|c|c|c|}
\hline \multirow[b]{2}{*}{ Gene $^{2}$} & \multicolumn{2}{|c|}{$1 \mathrm{wpp}$} & \multicolumn{2}{|c|}{5 mges } \\
\hline & Fertil+ & Fertil- & Fertil+ & Fertil- \\
\hline \multicolumn{5}{|l|}{ Cluster 1} \\
\hline PLIN1 & $2.02 \mathrm{E}+00 \pm 3.02 \mathrm{E}-01^{\mathrm{b}}$ & $2.06 \mathrm{E}+00 \pm 2.67 \mathrm{E}-01^{\mathrm{b}}$ & $8.11 \mathrm{E}-01 \pm 1.81 \mathrm{E}-01^{\mathrm{a}}$ & $7.60 \mathrm{E}-01 \pm 1.43 \mathrm{E}-01^{\mathrm{a}}$ \\
\hline LIPE & $5.22 \mathrm{E}-01 \pm 8.52 \mathrm{E}-02^{\mathrm{b}}$ & $6.15 \mathrm{E}-01 \pm 1.00 \mathrm{E}-01^{\mathrm{b}}$ & $1.87 \mathrm{E}-01 \pm 7.38 \mathrm{E}-02^{\mathrm{a}}$ & $1.85 \mathrm{E}-01 \pm 5.27 \mathrm{E}-02^{\mathrm{a}}$ \\
\hline $\mathrm{FABP}_{4}$ & $3.71 \mathrm{E}+01 \pm 8.44 \mathrm{E}+00^{\mathrm{b}}$ & $4.49 \mathrm{E}+01 \pm 7.99 \mathrm{E}+00^{\mathrm{b}}$ & $8.06 \mathrm{E}+00 \pm 1.89 \mathrm{E}+00^{\mathrm{a}}$ & $9.87 \mathrm{E}+00 \pm 1.78 \mathrm{E}+00^{\mathrm{a}}$ \\
\hline RARRES2 & $2.50 \mathrm{E}+00 \pm 3.57 \mathrm{E}-01^{\mathrm{b}}$ & $2.33 \mathrm{E}+00 \pm 2.58 \mathrm{E}-01^{\mathrm{b}}$ & $1.29 \mathrm{E}+00 \pm 6.74 \mathrm{E}-02^{\mathrm{a}}$ & $1.58 \mathrm{E}+00 \pm 3.67 \mathrm{E}-01^{\mathrm{a}}$ \\
\hline CPT2 & $2.47 \mathrm{E}-02 \pm 3.89 \mathrm{E}-03^{\mathrm{ab}}$ & $2.82 \mathrm{E}-02 \pm 6.29 \mathrm{E}-03^{\mathrm{b}}$ & $1.70 \mathrm{E}-02 \pm 1.74 \mathrm{E}-03^{\mathrm{a}}$ & $2.15 \mathrm{E}-02 \pm 5.58 \mathrm{E}-03^{\mathrm{ab}}$ \\
\hline ADIPOR2 & $6.81 \mathrm{E}-01 \pm 1.22 \mathrm{E}-01^{\mathrm{b}}$ & $1.01 \mathrm{E}+00 \pm 1.33 \mathrm{E}-01^{\mathrm{c}}$ & $4.06 \mathrm{E}-01 \pm 1.03 \mathrm{E}-01^{\mathrm{a}}$ & $4.17 \mathrm{E}-01 \pm 9.52 \mathrm{E}-02^{\mathrm{a}}$ \\
\hline$A D I P O Q$ & $5.54 \mathrm{E}+00 \pm 9.32 \mathrm{E}-01^{\mathrm{a}, \mathrm{x}}$ & $8.26 \mathrm{E}+00 \pm 6.93 \mathrm{E}-01^{\mathrm{b}}$ & $3.97 \mathrm{E}+00 \pm 7.08 \mathrm{E}-01^{\mathrm{a}, \mathrm{y}}$ & $3.82 \mathrm{E}+00 \pm 8.14 \mathrm{E}-01^{\mathrm{a}, \mathrm{y}}$ \\
\hline \multicolumn{5}{|c|}{ 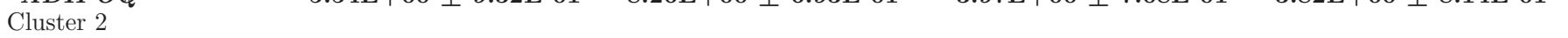 } \\
\hline SPTA1 & $1.57 \mathrm{E}-05 \pm 3.76 \mathrm{E}-06^{\mathrm{a}}$ & $1.55 \mathrm{E}-05 \pm 4.54 \mathrm{E}-06^{\mathrm{a}}$ & $2.00 \mathrm{E}-05 \pm 2.72 \mathrm{E}-06^{\mathrm{a}}$ & $2.28 \mathrm{E}-05 \pm 6.58 \mathrm{E}-06^{\mathrm{a}}$ \\
\hline$A C A C A$ & $9.38 \mathrm{E}-03 \pm 1.46 \mathrm{E}-03^{\mathrm{ab}, \mathrm{x}}$ & $7.12 \mathrm{E}-03 \pm 1.25 \mathrm{E}-03^{\mathrm{a}}$ & $2.22 \mathrm{E}-02 \pm 8.55 \mathrm{E}-03^{\mathrm{bc}, \mathrm{y}}$ & $3.04 \mathrm{E}-02 \pm 1.44 \mathrm{E}-02^{\mathrm{c}}$ \\
\hline$S C D$ & $7.52 \mathrm{E}-02 \pm 2.04 \mathrm{E}-02^{\mathrm{a}}$ & $1.02 \mathrm{E}-01 \pm 2.96 \mathrm{E}-02^{\mathrm{a}}$ & $3.31 \mathrm{E}+00 \pm 1.14 \mathrm{E}+00^{\mathrm{b}}$ & $2.38 \mathrm{E}+00 \pm 1.06 \mathrm{E}+00^{\mathrm{b}}$ \\
\hline ADIPOR1 & $1.41 \mathrm{E}-01 \pm 2.80 \mathrm{E}-02^{\mathrm{a}}$ & $1.31 \mathrm{E}-01 \pm 2.39 \mathrm{E}-02^{\mathrm{a}}$ & $1.02 \mathrm{E}-01 \pm 1.42 \mathrm{E}-02^{\mathrm{a}}$ & $1.24 \mathrm{E}-01 \pm 3.94 \mathrm{E}-02^{\mathrm{a}}$ \\
\hline$R E T N$ & $1.47 \mathrm{E}-02 \pm 3.73 \mathrm{E}-03^{\mathrm{b}}$ & $1.16 \mathrm{E}-02 \pm 1.80 \mathrm{E}-03^{\mathrm{ab}}$ & $7.29 \mathrm{E}-03 \pm 6.78 \mathrm{E}-04^{\mathrm{a}}$ & $1.01 \mathrm{E}-02 \pm 3.55 \mathrm{E}-03^{\mathrm{ab}}$ \\
\hline$A D A R$ & $1.26 \mathrm{E}-01 \pm 1.72 \mathrm{E}-02^{\mathrm{b}}$ & $1.09 \mathrm{E}-01 \pm 9.53 \mathrm{E}-03^{\mathrm{b}}$ & $6.63 \mathrm{E}-02 \pm 5.15 \mathrm{E}-03^{\mathrm{a}}$ & $1.19 \mathrm{E}-01 \pm 3.41 \mathrm{E}-02^{\mathrm{b}}$ \\
\hline PLIN2 & $9.76 \mathrm{E}-02 \pm 1.60 \mathrm{E}-02^{\mathrm{ab}}$ & $1.33 \mathrm{E}-01 \pm 2.19 \mathrm{E}-02^{\mathrm{b}}$ & $8.04 \mathrm{E}-02 \pm 1.28 \mathrm{E}-02^{\mathrm{a}}$ & $1.04 \mathrm{E}-01 \pm 2.40 \mathrm{E}-02^{\mathrm{ab}}$ \\
\hline SHC1 & $1.24 \mathrm{E}-01 \pm 2.24 \mathrm{E}-02^{\mathrm{b}}$ & $9.40 \mathrm{E}-02 \pm 1.44 \mathrm{E}-02^{\mathrm{ab}}$ & $8.88 \mathrm{E}-02 \pm 1.10 \mathrm{E}-02^{\mathrm{a}}$ & $8.12 \mathrm{E}-02 \pm 1.51 \mathrm{E}-02^{\mathrm{a}}$ \\
\hline$N A M P T$ & $1.16 \mathrm{E}-02 \pm 1.98 \mathrm{E}-03^{\mathrm{a}}$ & $1.26 \mathrm{E}-02 \pm 1.10 \mathrm{E}-03^{\mathrm{ab}}$ & $9.38 \mathrm{E}-03 \pm 1.72 \mathrm{E}-03^{\mathrm{a}}$ & $2.18 \mathrm{E}-02 \pm 1.11 \mathrm{E}-02^{\mathrm{b}}$ \\
\hline$T N F$ & $5.16 \mathrm{E}-05 \pm 1.39 \mathrm{E}-05^{\mathrm{a}}$ & $6.30 \mathrm{E}-05 \pm 1.60 \mathrm{E}-05^{\mathrm{a}}$ & $5.18 \mathrm{E}-05 \pm 1.21 \mathrm{E}-05^{\mathrm{a}}$ & $8.76 \mathrm{E}-05 \pm 2.85 \mathrm{E}-05^{\mathrm{a}}$ \\
\hline PAQR 6 & $3.32 \mathrm{E}-01 \pm 4.15 \mathrm{E}-02^{\mathrm{ab}}$ & $2.58 \mathrm{E}-01 \pm 4.74 \mathrm{E}-02^{\mathrm{a}}$ & $3.30 \mathrm{E}-01 \pm 5.12 \mathrm{E}-02^{\mathrm{ab}}$ & $4.13 \mathrm{E}-01 \pm 8.34 \mathrm{E}-02^{\mathrm{b}}$ \\
\hline
\end{tabular}

${ }^{\mathrm{a}-\mathrm{c}}$ Means within a row without a common letter differ $(P<0.05)$.

${ }^{\mathrm{x}, \mathrm{y}}$ Means within a row without a common letter tend to differ $(P<0.10)$.

${ }^{1}$ Relative expression was measured relatively to the geometric mean of 4 housekeeping gene expression [cyclophilin A (PPIA), GAPDH, ribosomic protein S9 (RPS9), and ribosomal protein L19 (RPL19)] by real-time reverse-transcription PCR. Results are presented as means \pm SEM. Genes and expression values written in bold indicate genes with difference in expression between both haplotypes.

${ }^{2}$ PLIN1 = perilipin LIPE $=$ hormone-sensitive lipase $F A B P 4=$ FA-binding protein $4 ; R A R R E S 2=$ chemerin; CPT1 $=$ carnitine palmitoyl transferase $1 ; L E P R=$ leptin receptor long form; $C P T 2=$ carnitine palmitoyl transferase $2 ; A D I P O R 2=$ adiponectin receptor $2 ; A D I P O Q$ $=$ adiponectin SPTA1 $=$ spectrin $\alpha$ erythrocytic; $A C A C A=$ acetyl CoA carboxylase; $S C D=$ stearoyl-CoA desaturase $1 ; M T X 1=$ metaxin $1 ; L E P=$ leptin; $F A S N=$ FA synthase; $A D I P O R 1=$ adiponectin receptor $1 ; R E T N=$ resistin; $A D A R=$ adenosine deaminase, RNA specific; $P L I N 2=$ adipophilin; $S H C 1=$ Src homology 2 domain containing; $N A M P T=$ visfatin; $T N F=$ tumor necrosis factor $\alpha ; P A Q R 6=$ progestin and adipoQ receptor.

as well as in swine (Chappaz et al., 2008). The significant difference in $A D I P O Q$ and $A D I P O R 2$ mRNA expression together with previous findings reported in the literature suggest that adiponectin or a metabolic pathway mediated by adiponectin could be involved in the difference in fertility observed between the Fertil+ and Fertil- haplotypes (Coyral-Castel et al., 2011). Further studies on adiponectin expression and function are still needed to fully understand by which mechanism it could affect fertility.

During their first lactation, Fertil+ and Fertil- cows exhibited differences in fertility at first service and our analysis of zootechnical and metabolic parameters suggested a difference in body reserve mobilization. Actually, no demonstrated difference in BCS or in 305-d milk production exists between the haplotypes (CoyralCastel et al., 2012b). Nevertheless, in early lactation,
Fertil- cows had a greater negative energy balance and although BW 1 wk before calving and BW of calves were similar between haplotypes, Fertil+ cows were heavier (Coyral-Castel et al., 2012b), which could suggest a quicker loss of energy reserves for Fertil- cows, corresponding to the NEFA measurement at the 1wpp biopsy. Thus, the Fertil- haplotype tends to have a greater degree of mobilization of its body reserves, potentially playing a role in the difference in fertility between the 2 groups.

Our candidate gene approach enabled us to find 2 clusters of genes: cluster 1 overexpressed at $1 \mathrm{wpp}$ during mobilization (ADIPOR2, LEPR, RARRES2, PLIN1, LIPE, FABP4, CPT1A, and ADIPOQ) and cluster 2 overexpressed at 5mges during reconstitution (FASN, SCD, ACACA, and MTX1) of body reserves. Concerning protein expression data, the same differ- 


\section{Correlations}
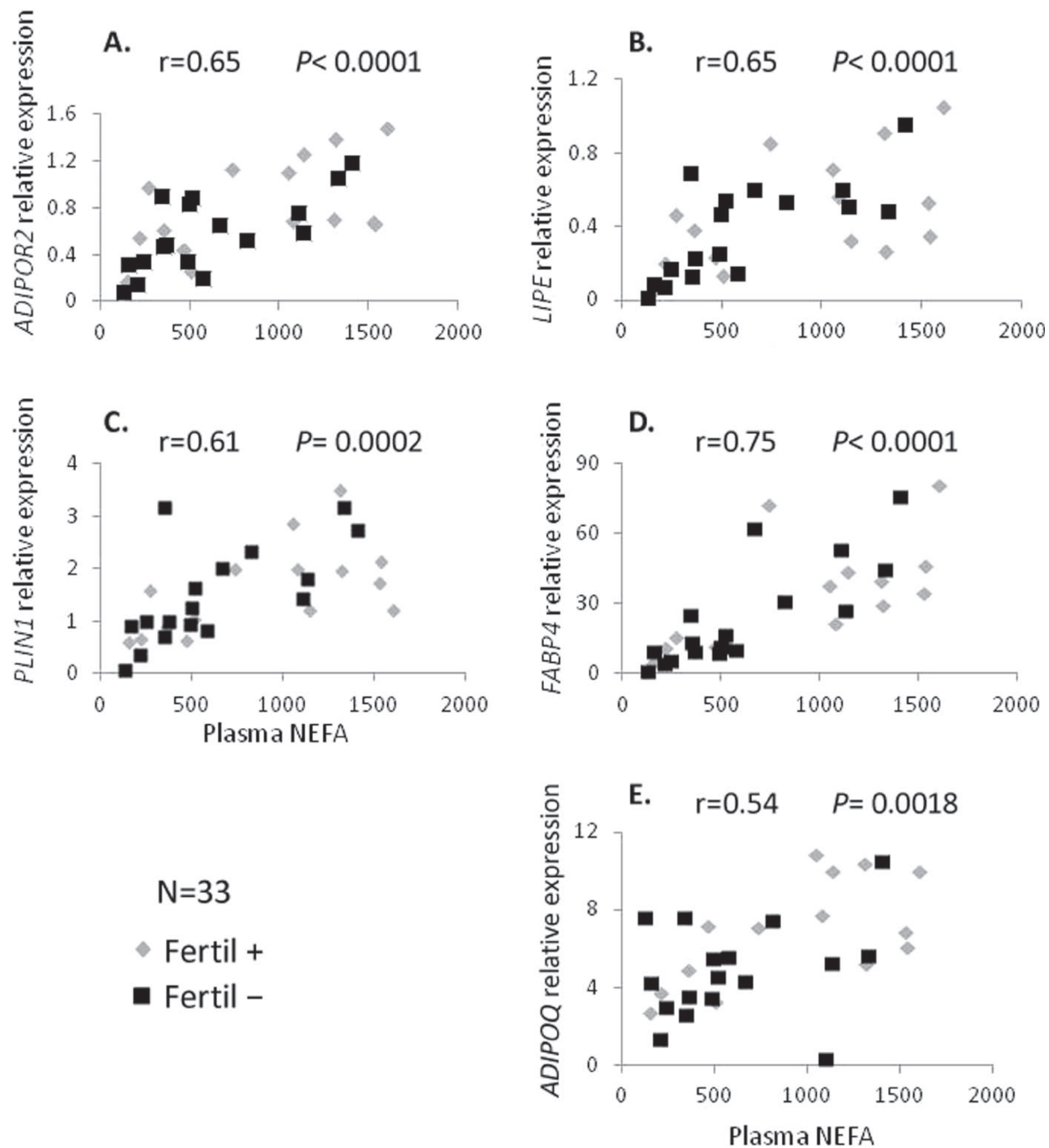

Figure 3. Correlations between mRNA expression and plasma NEFA level. Real-time PCR analysis was performed in duplicate on samples at 2 different stages in Fertil- and Fertil+ haplotypes (exhibiting 69 and 39\% pregnancy rate at first service, respectively), with 6 to 9 biological replicates. Total adipose tissue RNA at 1 wk postpartum (1wpp) and 5 mo of gestation (5mges) of each haplotype were extracted as described in the Materials and Methods section. Correlations were measured between gene expression and plasma NEFA level in each haplotype. Distributions are represented for 4 genes: (A) adiponectin receptor 2 (ADIPOR2), (B) hormone-sensitive lipase (LIPE), (C) perilipin (PLIN1), (D) FA-binding protein $4(F A B P 4)$, and $(\mathrm{E})$ adiponectin $(A D I P O Q)$. Values of $\mathrm{r}$ and significance of the correlations are indicated on the graphs. Correlations were considered as significant if $\mathrm{r}>0.5$ and $P<0.01$. 


\section{SCD protein}

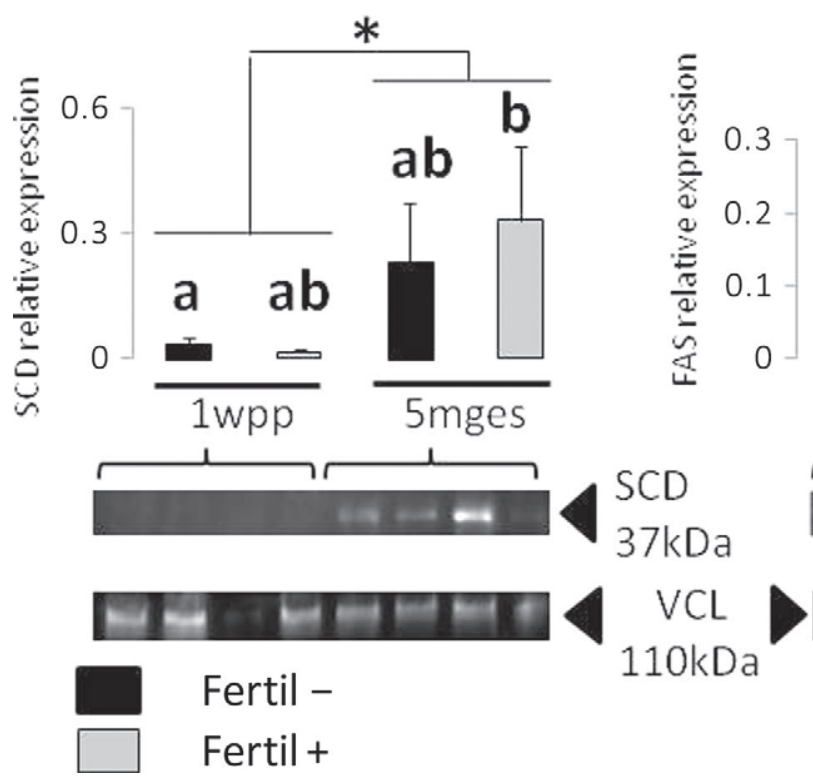

FAS protein

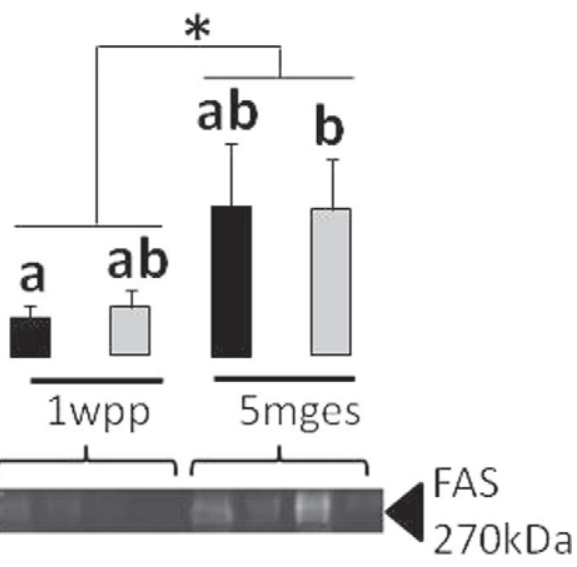

Figure 4. Western blotting analysis of protein expression levels in adipose tissue. The Western blotting data provided represent the related expression of stearoyl-CoA desaturase 1 (SCD) and FA synthase (FAS) at the mobilization stage [1 wk postpartum (1wpp)] and reconstitution

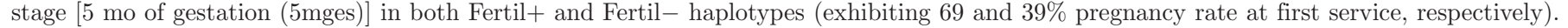

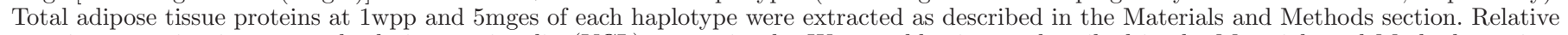
protein expression is measured relative to vinculin (VCL) expression by Western blotting as described in the Materials and Methods section.

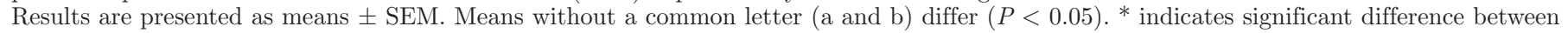
1 wpp and 5mges stages $(P<0.05)$.

ences in expression as for mRNA were found for SCD and FAS, 2 intracellular proteins. Some protein data were not similar to mRNA data, probably because the proteins measured were either adipokines or membrane receptors. Indeed, adipokines are secreted proteins with mRNA expression that cannot be correlated to intracellular protein level, and membrane receptors are more difficult to analyze by Western blotting than intracellular proteins (Schwanhausser et al., 2011).

Two genes (NAMPT and ADAR) showed a significant difference between haplotypes at 5 mges. However, 5 mges being a stage of gestation, this observed expression difference was probably not related to difference in fertility. One of the positional candidate genes belonging to QTL-Fert-F-BTA3 $[A D A R$, related to ovarian neoplasm in human (Urunsak et al., 2012)] also showed a difference in expression between the 2 haplotypes studied. Thus, a similar study should be done in reproductive tissues to investigate whether QTL genes could play a role in the difference in fertility observed.

Moreover, 5 genes (LIPE, PLIN1, FABP 4, ADIPOQ, and $A D I P O R 2)$ had their expression positively correlated with plasma NEFA levels, suggesting that a high mRNA level of these 5 genes in adipose tissue could indicate intense mobilization of body reserve.
Hormone-sensitive lipase, PLIN1, and FABP 4 are involved in the first step of lipolysis and thus are a likely cause of NEFA concentration increase. Hence, it is coherent that these 3 genes are positively correlated to NEFA level. Adiponectin and ADIPOR2 expression was also upregulated when NEFA level was enhanced. Indeed, ADIPOR2 expression in the bovine liver was upregulated when prepartum energy intake had been restricted (Loor et al., 2006). The FFA level seems to be the signal that causes ADIPOQ and ADIPOR2 overexpression (Sukumaran et al., 2010).

\section{CONCLUSIONS}

In this paper, we studied adipokine mRNA expression in adipose tissue from 2 groups of dairy cows differing for a female fertility QTL (QTL-Fert-F-BTA3 in Fertil- and Fertil+ haplotypes) at 2 physiological states of either mobilization or reconstitution of body reserves. We found 2 clusters of genes either involved in lipolysis and FA oxidation process, or involved in the FA synthesis process. One positional candidate gene located within the QTL $(A D A R)$ was differentially expressed between the haplotypes during the gestation stage. Interestingly, fat $A D I P O Q$ and $A D I P O R 2$ 
mRNA expression 1 wk after calving was positively correlated with NEFA level and thus with mobilization of body reserves. Moreover, these were the only genes that showed a significant difference in mRNA expression between both haplotypes at the mobilization stage. Adiponectin is already known to affect ovarian steroidogenesis in several species. Further studies are necessary to determine whether adiponectin could be a reliable fertility marker.

\section{ACKNOWLEDGMENTS}

We thank the technical staff of l'Unité Expérimentale de Physiologie Animale de l'Orfrasière (UEPAO) in Nouzilly, France (Mickael Dupont, Mickael Delanoue, Christophe Mouaze, Ludovic Métivier, and Damien Capo). The authors also acknowledge Philippe Monget at INRA Nouzilly (France) for helpful scientific discussion and Philippe Faverdin, Thibaud Le Mouel, Marie Le Tilly and Colette Mustiere at the INRA Rennes (France) for NEFA and glucose assays. This work was financially supported by Institut National de la Recherche Agronomique and partly by the programs ANR "Fertilité1", ANR "Fertilité2," and ApisGene. This research did not receive any specific grant from any funding agency in the public, commercial, or notfor-profit sector.

\section{REFERENCES}

Ben Jemaa, S., S. Fritz, F. Guillaume, T. Druet, C. Denis, A. Eggen, and M. Gautier. 2008. Detection of quantitative trait loci affecting non-return rate in French dairy cattle. J. Anim. Breed. Genet. 125:280-288.

Bornstein, P., C. E. McKinney, M. E. LaMarca, S. Winfield, T. Shingu, S. Devarayalu, H. L. Vos, and E. I. Ginns. 1995. Metaxin, a gene contiguous to both thrombospondin 3 and glucocerebrosidase, is required for embryonic development in the mouse: Implications for Gaucher disease. Proc. Natl. Acad. Sci. USA 92:4547-4551.

Briana, D. D., and A. Malamitsi-Puchner. 2010. The role of adipocytokines in fetal growth. Ann. N. Y. Acad. Sci. 1205:82-87.

Butler, W. R. 1998. Review: Effect of protein nutrition on ovarian and uterine physiology in dairy cattle. J. Dairy Sci. 81:2533-2539.

Butler, W. R. 2000. Nutritional interactions with reproductive performance in dairy cattle. Anim. Reprod. Sci. 60-61:449-457.

Campos, D. B., M.-F. Palin, V. Bordignon, and B. D. Murphy. 2008. The 'beneficial' adipokines in reproduction and fertility. Int. J. Obes. (Lond.) 32:223-231.

Chappaz, E., M. S. Albornoz, D. Campos, L. Che, M. F. Palin, B. D. Murphy, and V. Bordignon. 2008. Adiponectin enhances in vitro development of swine embryos. Domest. Anim. Endocrinol. 35:198-207.

Combs, T. P., U. B. Pajvani, A. H. Berg, Y. Lin, L. A. Jelicks, M. Laplante, A. R. Nawrocki, M. W. Rajala, A. F. Parlow, L. Cheeseboro, Y.-Y. Ding, R. G. Russell, D. Lindemann, A. Hartley, G. R. C. Baker, S. Obici, Y. Deshaies, M. Ludgate, L. Rossetti, and P. E. Scherer. 2004. A transgenic mouse with a deletion in the collagenous domain of adiponectin displays elevated circulating adiponectin and improved insulin sensitivity. Endocrinology 145:367-383.

Coyral-Castel, S., D. Brisard, J. L. Touzé, M. Dupont, C. Ramé, S. Uzbekova, and J. Dupont. 2012a. Analysis of in vivo oocyte maturation, in vitro embryo development and gene expression in cumulus cells of dairy cows and heifers selected for one fertility quantitative trait loci (QTL) located on BTA3. Theriogenology 77:1822-1833.e1.

Coyral-Castel, S., P. Faverdin, C. Ramé, S. Fréret, D. Guillaume, S. Fritz, and J. Dupont. 2012b. Significant differences in fertility between dairy cows selected for one QTL located on bovine chromosome 3 are not attributable to energy balance, although eating behaviour is affected. Animal 7:610-617.

Coyral-Castel, S., C. Rame, D. Monniaux, S. Fréret, C. Fabre-Nys, S. Fritz, P. Monget, F. Dupont, and J. Dupont. 2011. Ovarian parameters and fertility of dairy cows selected for one QTL located on BTA3. Theriogenology 75:1239-1250.

Dezső, Z., Y. Nikolsky, E. Sviridov, W. Shi, T. Serebriyskaya, D. Dosymbekov, A. Bugrim, E. Rakhmatulin, R. J. Brennan, A. Guryanov, K. Li, J. Blake, R. R. Samaha, and T. Nikolskaya. 2008. A comprehensive functional analysis of tissue specificity of human gene expression. BMC Biol. 6:49.

Diskin, M. G., D. R. Mackey, J. F. Roche, and J. M. Sreenan. 2003. Effects of nutrition and metabolic status on circulating hormones and ovarian follicle development in cattle. Anim. Reprod. Sci. 78:345-370.

Druet, T., S. Fritz, M. Boussaha, S. Ben-Jemaa, F. Guillaume, D. Derbala, D. Zelenika, D. Lechner, C. Charon, D. Boichard, I. G. Gut, A. Eggen, and M. Gautier. 2008. Fine mapping of quantitative trait loci affecting female fertility in dairy cattle on BTA03 using a dense single-nucleotide polymorphism map. Genetics 178:2227-2235.

Dupont, J., M. Reverchon, L. Cloix, P. Froment, and C. Ramé. 2012. Involvement of adipokines, AMPK, PI3K and the PPAR signaling pathways in ovarian follicle development and cancer. Int. J. Dev. Biol. 56:959-967.

Eisen, M. B., P. T. Spellman, P. O. Brown, and D. Botstein. 1998. Cluster analysis and display of genome-wide expression patterns. Proc. Natl. Acad. Sci. USA 95:14863-14868.

Elkins, D. A., and D. M. Spurlock. 2009. Phosphorylation of perilipin is associated with indicators of lipolysis in Holstein cows. Horm. Metab. Res. 41:736-740.

Flowers, M. T., and J. M. Ntambi. 2009. Stearoyl-CoA desaturase and its relation to high-carbohydrate diets and obesity. Biochim. Biophys. Acta 1791:85-91.

Foufelle, F., J. Girard, and P. Ferré. 1996. Regulation of lipogenic enzyme expression by glucose in liver and adipose tissue: A review of the potential cellular and molecular mechanisms. Adv. Enzyme Regul. 36:199-226.

Fruebis, J., T.-S. Tsao, S. Javorschi, D. Ebbets-Reed, M. R. Erickson, F. T. Yen, B. E. Bihain, and H. F. Lodish. 2001. Proteolytic cleavage product of $30-\mathrm{kDa}$ adipocyte complement-related protein increases fatty acid oxidation in muscle and causes weight loss in mice. Proc. Natl. Acad. Sci. USA 98:2005-2010.

Griffin, M. J., and H. S. Sul. 2004. Insulin regulation of fatty acid synthase gene transcription: Roles of USF and SREBP-1c. IUBMB Life 56:595-600.

Grummer, R. R., P. C. Hoffman, M. L. Luck, and S. J. Bertics. 1995. Effect of prepartum and postpartum dietary energy on growth and lactation of primiparous cows. J. Dairy Sci. 78:172-180.

Guillaume, F., M. Gautier, S. Ben Jemaa, S. Fritz, A. Eggen, D. Boichard, and T. Druet. 2007. Refinement of two female fertility QTL using alternative phenotypes in French Holstein dairy cattle. Anim. Genet. 38:72-74.

Kadowaki, T., and T. Yamauchi. 2005. Adiponectin and adiponectin receptors. Endocr. Rev. 26:439-451.

Karastergiou, K., and V. Mohamed-Ali. 2010. The autocrine and paracrine roles of adipokines. Mol. Cell. Endocrinol. 318:69-78.

Klebanov, S., C. M. Astle, O. DeSimone, V. Ablamunits, and D. E. Harrison. 2005. Adipose tissue transplantation protects $o b / o b$ mice from obesity, normalizes insulin sensitivity and restores fertility. J. Endocrinol. 186:203-211.

Komatsu, T., F. Itoh, S. Mikawa, and K. Hodate. 2003. Gene expression of resistin in adipose tissue and mammary gland of lactating and non-lactating cows. J. Endocrinol. 178:R1-R5. 
Lagaly, D. V., P. Y. Aad, J. A. Grado-Ahuir, L. B. Hulsey, and L. J. Spicer. 2008. Role of adiponectin in regulating ovarian theca and granulosa cell function. Mol. Cell. Endocrinol. 284:38-45.

Lemor, A., A. Hosseini, H. Sauerwein, and M. Mielenz. 2009. Transition period-related changes in the abundance of the mRNAs of adiponectin and its receptors, of visfatin, and of fatty acid binding receptors in adipose tissue of high-yielding dairy cows. Domest. Anim. Endocrinol. 37:37-44.

Leroy, J. L., T. Vanholder, A. T. Van Knegsel, I. Garcia-Ispierto, and P. E. Bols. 2008. Nutrient prioritization in dairy cows early postpartum: Mismatch between metabolism and fertility? Reprod. Domest. Anim. 43(Suppl. 2):96-103.

Loor, J. J., H. M. Dann, N. A. Guretzky, R. E. Everts, R. Oliveira, C. A. Green, N. B. Litherland, S. L. Rodriguez-Zas, H. A. Lewin, and J. K. Drackley. 2006. Plane of nutrition prepartum alters hepatic gene expression and function in dairy cows as assessed by longitudinal transcript and metabolic profiling. Physiol. Genomics $27: 29-41$.

Maillard, V., P. Froment, C. Rame, S. Uzbekova, S. Elis, and J. Dupont. 2011. Expression and effect of resistin on bovine and rat granulosa cell steroidogenesis and proliferation. Reproduction 141:467-479.

Maillard, V., S. Uzbekova, F. Guignot, C. Perreau, C. Ramé, S. Coyral-Castel, and J. Dupont. 2010. Effect of adiponectin on bovine granulosa cell steroidogenesis, oocyte maturation and embryo development. Reprod. Biol. Endocrinol. 8:23.

Mitchell, M., D. T. Armstrong, R. L. Robker, and R. J. Norman. 2005. Adipokines: Implications for female fertility and obesity. Reproduction 130:583-597.

Narasimhan, M. L., M. A. Coca, J. Jin, T. Yamauchi, Y. Ito, T. Kadowaki, K. K. Kim, J. M. Pardo, B. Damsz, P. M. Hasegawa, D.-J. Yun, and R. A. Bressan. 2005. Osmotin is a homolog of mammalian adiponectin and controls apoptosis in yeast through a homolog of mammalian adiponectin receptor. Mol. Cell 17:171-180.

Pereira, M., Jr., D. B. Vidotti, R. C. Borra, M. De Jesus Simões, I. D. C. G. Da Silva, and M. A. Haidar. 2011. Involvement of GDF-9, leptin, and IGF1 receptors associated with adipose tissue transplantation on fertility restoration in obese anovulatory mice. Gynecol. Endocrinol. 27:759-766.

Richards, J. S., Z. Liu, T. Kawai, K. Tabata, H. Watanabe, D. Suresh, F.-T. Kuo, M. D. Pisarska, and M. Shimada. 2012. Adiponectin and its receptors modulate granulosa cell and cumulus cell functions, fertility, and early embryo development in the mouse and human. Fertil. Steril. 98:471-479.e1.

Roche, J. F. 2006. The effect of nutritional management of the dairy cow on reproductive efficiency. Anim. Reprod. Sci. 96:282-296.

Rozen, S., and H. J. Skaletsky. 2000. Primer3 on the WWW for general users and for biologist programmers. Pages 365-386 in Bioinformatics Methods and Protocols: Methods in Molecular Biology. S. Misener and S. A. Krawetz, ed. Humana Press, Totowa, NJ.

Sadri, H., M. Mielenz, I. Morel, R. M. Bruckmaier, and H. A. van Dorland. 2011. Plasma leptin and mRNA expression of lipogenesis and lipolysis-related factors in bovine adipose tissue around parturition. J. Anim. Physiol. Anim. Nutr. (Berl.) 95:790-797.
SAS Institute. 2009. SAS/STAT 9.2 User's Guide. 2nd ed. SAS institute Inc., Cary, NC.

Schröder, U. J., and R. Staufenbiel. 2006. Invited review: Methods to determine body fat reserves in the dairy cow with special regard to ultrasonographic measurement of backfat thickness. J. Dairy Sci. 89:1-14.

Schwanhäusser, B., D. Busse, N. Li, G. Dittmar, J. Schuchhardt, J. Wolf, W. Chen, and M. Selbach. 2011. Global quantification of mammalian gene expression control. Nature 473:337-342.

Shen, W.-J., K. Sridhar, D. A. Bernlohr, and F. B. Kraemer. 1999. Interaction of rat hormone-sensitive lipase with adipocyte lipidbinding protein. Proc. Natl. Acad. Sci. USA 96:5528-5532.

Song, S.-H., K. Fukui, K. Nakajima, T. Kozakai, S. Sasaki, S.-G. Roh, and K. Katoh. 2010. Cloning, expression analysis, and regulatory mechanisms of bovine chemerin and chemerin receptor. Domest. Anim. Endocrinol. 39:97-105.

Spicer, L. J., N. B. Schreiber, D. V. Lagaly, P. Y. Aad, L. B. Douthit, and J. A. Grado-Ahuir. 2011. Effect of resistin on granulosa and theca cell function in cattle. Anim. Reprod. Sci. 124:19-27.

Staples, C. R., J. M. Burke, and W. W. Thatcher. 1998. Influence of supplemental fats on reproductive tissues and performance of lactating cows. J. Dairy Sci. 81:856-871.

Su, A. I., M. P. Cooke, K. A. Ching, Y. Hakak, J. R. Walker, T. Wiltshire, A. P. Orth, R. G. Vega, L. M. Sapinoso, A. Moqrich, A. Patapoutian, G. M. Hampton, P. G. Schultz, and J. B. Hogenesch. 2002. Large-scale analysis of the human and mouse transcriptomes. Proc. Natl. Acad. Sci. USA 99:4465-4470.

Sukumaran, S., B. Xue, W. J. Jusko, D. C. Dubois, and R. R. Almon. 2010. Circadian variations in gene expression in rat abdominal adipose tissue and relationship to physiology. Physiol. Genomics 42A:141-152.

Sumner, J. M., and J. P. McNamara. 2007. Expression of lipolytic genes in the adipose tissue of pregnant and lactating Holstein dairy cattle. J. Dairy Sci. 90:5237-5246.

Sumner-Thomson, J. M., J. L. Vierck, and J. P. McNamara. 2011. Differential expression of genes in adipose tissue of first-lactation dairy cattle. J. Dairy Sci. 94:361-369.

Tersigni, C., F. Di Nicuolo, S. D'Ippolito, M. Veglia, M. Castellucci, and N. Di Simone. 2011. Adipokines: New emerging roles in fertility and reproduction. Obstet. Gynecol. Surv. 66:47-63.

Thorn, S. R., R. A. Ehrhardt, W. R. Butler, S. M. Quirk, and Y. R. Boisclair. 2008. Insulin regulates hepatic leptin receptor expression in early lactating dairy cows. Am. J. Physiol. Regul. Integr. Comp. Physiol. 295:R1455-R1462.

Urunsak, I. F., U. K. Gulec, S. Paydas, G. Seydaoglu, A. B. Guzel, and M. A. Vardar. 2012. Adenosine deaminase activity in patients with ovarian neoplasms. Arch. Gynecol. Obstet.

Yeaman, S. J., G. M. Smith, C. A. Jepson, S. L. Wood, and N. Emmison. 1994. The multifunctional role of hormone-sensitive lipase in lipid metabolism. Adv. Enzyme Regul. 34:355-370.

Zhao, X., D. Mo, A. Li, W. Gong, Y. Zhang, W. Qian, W. Chen, S. Xiao, and Y. Chen. 2011. Characterization and transcriptional regulation analysis of the porcine PAQR6 gene. DNA Cell Biol. 30:947-954 